\title{
Pengaruh Good Governance dan Sistem Pengendalian Intern Pemerintah Pada Kinerja Pemerintah Daerah
}

\section{Gede Agus Sudiarsana Putra ${ }^{1}$ I Made Pande Dwiana Putra ${ }^{2}$}

\author{
${ }^{1}$ Fakultas Ekonomi dan Bisnis Universitas Udayana (Unud), Bali, Indonesia \\ email: agussudiarsana95@gmail.com/ Telp: 081338513741 \\ ${ }^{2}$ Fakultas Ekonomi dan Bisnis Universitas Udayana (Unud), Bali, Indonesia
}

\begin{abstract}
ABSTRAK
Pemerintah sebagai agen dari masyarakat dituntut untuk mampu mempertanggungjawabkan kinerjanya. Kineja yang baik dapat dilihat dari penerapan good governance dan sistem pengendalian intern pemerintah di suatu instansi pemerintahan. Penelitian ini bertujuan untuk mengetahui apakah terdapat pengaruh Good Governance dan Sistem Pengendalian Intern Pemerintah pada Kinerja Pemerintah Daerah Kabupaten Karangasem.Penelitian dilakukan pada Pemerintah Kabupaten Karangasem dengan menjadikan 152 orang pejabat yang tersebar dalam 38 Organisasi Perangkat Daerah (OPD) sebagai sampel, dengan metode purposive sampling. Pengumpulan data dilakukan dengan menyebarkan kuesioner dan teknik analisis dengan teknik analisis regresi linier berganda.Berdasarkan hasil analisis, diketahui bahwaGood Governance dan Sistem Pengendalian Intern Pemerintah memiliki pengaruh positif pada Kinerja Pemerintah Kabupaten Karangasem, artinya semakin baik penerapan good governance dan sistem pengendalian intern pemerintah maka semakin baik pula Kinerja Pemerintah Kabupaten Karangasem.

Kata kunci: good governance, sistem pengendalian intern, kinerja pemerintah
\end{abstract}

\begin{abstract}
The government as an agent of the community is required to be able to account for its performance. Good performance can be seen from the implementation of good governance and the government's internal control system in a government agency. This study aims to determine whether there is an influence of the Good Governance and the Government Internal Control System on the Performance of the Regional Government of Karangasem Regency. The study was conducted at the Government of Karangasem Regency by making 152 officials scattered in 38 Regional Device Organizations (OPD), with purposive sampling method. Based on the results of the analysis, it is known that Good Governance and the Government's Internal Control System have positive influence on the Performance of the Government of Karangasem Regency, meaning that the better the implementation of good governance and the government's internal control system, the better the Performance of the Karangasem District Government.

Keywords: good governance, internal control system, government performance
\end{abstract}

\section{PENDAHULUAN}

Akuntansi sektor publik saat ini khususnya di Indonesia semakin berkembang pesat seiring dengan adanya era baru dalam pelaksanaan otonomi daerah dan desentralisasi fiskal. Akuntasi sektor publik dapat menuntut sektor publik untuk bertanggungjawab terhadap kepentingan publik. Sektor publik merupakan 
I Gede Agus Sudiarsana Putra dan I Made Pande Dwiana Putra. Pengaruh...

penyedia layanan terhadap kepentingan masyarakat yang paling utama di Indonesia. Sektor publik juga merupakan wahana bagi undang-undang untuk melaksanakan kebijakan sosial. Pemerintah daerah dituntut untuk melakukan pengelolaan keuangan daerah yang berorientasi pada publik (Mardiasmo, 2004). Adanya otonomi memberikan jalan bagi pemerintah daerah untuk mengelola dan melakukan pembaharuan sistem keuangan daerahnya sendiri.

Ketetapan Majelis Permusyawaratan Rakyat Nomor XV/MPR/1998 tentang penyelenggaraan otonomi daerah seperti pengaturan, pembagian dan pemanfaatan sumber daya nasional yang berkeadilan serta perimbangan keuangan pusat dan daerah dalam kerangka Negara Kesatuan Republik Indonesia merupakan landasan hukum bagi dikeluarkannya Undang-Undang Nomor 22 Tahun 1999 tentang Pemerintah Daerah. Undang-Undang Nomor 22 Tahun 1999 menyatakan bahwa otonomi daerah adalah wewenang yang dimiliki oleh daerah untuk mengatur dan mengurus masyarakatnya menurut kehendak sendiri berdasarkan aspirasi masyarakat sesuai peraturan perundang-undangan yang berlaku. Undang-undang tersebut diganti dan disempurnakan dengan UndangUndang Nomor 32 Tahun 2004 dan Undang-Undang Nomor 33 Tahun 2004 tentang pemerintah daerah. Kedua undang - undang tersebut telah merubah akuntabilitas atau pertanggungjawaban pemerintah dari pertanggungjawaban vertikal (pertanggungjawaban kepada pemerintah pusat) menjadi pertanggungjawaban horizontal (pertanggungjawaban kepada masyarakat melalui Dewan Perwakilan Rakyat). Hal tersebut membuat pemerintah sebagai 
penyelenggara pemerintahan dituntut harus mampu mempertanggungjawabkan kinerjanya kepada masyarakat.

Pengukuran akan kinerja pemerintah sangat penting, karena dengan terukurnya kinerja akan menciptakan kepercayaan masyarakat terhadap pemerintah, sehingga pembangunan disuatu daerah tepat sasaran. Wulandari (2011) menyatakan bahwa kinerja merupakan suatu prestasi yang telah dicapai oleh karyawan dalam merealisasikan sasaran organisasi yang telah ditetapkan. Keberhasilan kinerja pemerintah dapat diukur dengan laporan keuangan yang dilaporkan dan opini audit yang diberikan oleh Badan Pemeriksa Keuangan (BPK) kepada pemerintah daerah serta pelayanan pada kepentingan masyarakat. Kinerja pemerintah daerah juga dapat diukur dengan menggunakan instrumen yang dikembangkan oleh Wulandari (2011) yaitu pencapaian target kinerja kegiatan pada suatu program, ketetapan dan kesesuaian hasil, tingkat pencapaian program, dampak hasil kegiatan pada kehidupan masyarakat, kesesuaian realisasi anggaran dengan anggaran, pencapaian efisiensi operasional dan perilaku pegawai.

Pemerintah daerah sebagai pihak yang diberikan tugas menjalankan roda pemerintahan (pembangunan dan layanan sosial masyarakat) wajib menyampaikan pertanggungjawaban kinerja daerahnya untuk dinilai apakah pemerintah berhasil menjalankan tugasnya dengan baik (Ruspina, 2013). Diterapkannya Peraturan Pemerintah (PP) Nomor 60 Tahun 2008 tentang pemerintah daerah mengisyaratkan pemerintah daerah yang otonom diharapkan mendapat opini Wajar Tanpa Pengecualian (WTP) meskipun kenyataannya untuk 
I Gede Agus Sudiarsana Putra dan I Made Pande Dwiana Putra. Pengaruh...

mendapat opini WTP itu sangat sulit. Fenomena kinerja di pemerintah daerah, salah satunya di Kabupaten Karangasem, menunjukkan selama lima tahun terakhir mendapat opini yang berbeda sehingga Kabupaten Karangasem terus melakukan perubahan dan perbaikan dalam hal kinerja. Informasi lebih lengkap dapat dilihat di Tabel 1.

Tabel 1.

\begin{tabular}{cc}
\multicolumn{2}{c}{ Opini Audit BPK untuk Kabupaten Karangasem } \\
\hline Tahun & Opini Audit \\
\hline 2012 & Wajar Dengan Pengecualian \\
2013 & Wajar Dengan Pengecualian \\
2014 & Wajar Dengan Pengecualian \\
2015 & Wajar Tanpa Pengecualian \\
2016 & Wajar Tanpa Pengecualian
\end{tabular}

Sumber: BPK

Pemerintah Daerah Kabupaten Karangasem telah berhasil dalam melakukan perbaikan kualitas laporan keuangan selama lima tahun terakhir, tetapi BPK menemukan adanya temuan-temuan seperti lemahnya sistem pengendalian intern dalam penyusunan laporan keuangan seperti penatausahaan dan pengelolaaan aset tetap Pemerintah Kabupaten Karangasem, begitu pula penentuan azas kepatuhan terhadap ketentuan peraturan perundang-undangan dalam pengelolaan keuangan daerah seperti pengelolaan hibah Bantuan Operasional Sekolah (BOS) pada Dinas Pendidikan Pemuda Dan Olah Raga (DISDIKPORA) Kabupaten Karangasem belum tertib (Humas Protokol Setda Kab. Karangasem, 2016). Pemerintah Kabupaten Karangasem dalam hal ini masih banyak perlu melakukan perbaikan khususnya tata kelola pemerintahan dan sistem 
pengendalian intern, sehingga nantinya akan menghasilkan kinerja pemerintah yang lebih baik.

Adanya otonomi daerah pendayagunaan aparatur merupakan tuntutan bagi penyelenggara negara untuk mempraktikkan good governance yang mampu mendukung kelancaran dan keterpaduan pelaksanaan tugas dan fungsi penyelenggaraan negara dalam pembangunan. Good governance merupakan penggunaan wewenang untuk mengelola urusan-urusan negara pada semua tingkat baik dibagian ekonomi, politik dan administrasi. FCGI (2000) menyebutkan salah satu manfaat yang bisa dipetik dengan adanya good governance adalah meningkatkan kinerja melalui terciptanya proses pengambilan keputusan yang lebih baik, meningkatkan efisiensi operasional serta lebih meningkatkan pelayanan kepada publik.

Keberhasilan suatu organisasi pemerintah dapat diukur dengan perspektif pengelolaan keuangan daerah yang tepat dapat memberikan kepastian mengenai keberhasilan atau ketepatan suatu kegiatan sehingga pemerintah terus melakukan berbagai upaya untuk meningkatkan transparansi dan akuntabilitas pengelolaan keuangan daerahnya (Ruspina, 2013). Keberhasilan suatu pemerintahan juga dapat diukur dari pelayanan pemerintah terhadap masyarakatnya sendiri, dimana masyarakat dapat merasakan pelayanan pemerintah dengan merata dan berkeadialan. Good governance memiliki beberapa prinsip untuk mewujudkannya yaitu: partisipasi, aturan hukum, transparansi, daya tanggap, kesetaraan, efektifitas dan efisiensi, akuntabilitas, dan visi strategik (Badruzaman dan Chairunnisa, 2011). Good governance juga diharapkan memberikan manfaat untuk 
I Gede Agus Sudiarsana Putra dan I Made Pande Dwiana Putra. Pengaruh...

meningkatkan kemampuan operasional suatu pemerintahan, meningkatkan pelayanan terhadap stakeholder dan dengan proses pengambilan keputusan yang tepat diharapkan mampu meningkatkan kinerja pemerintah. Jika tata kelola pemerintahan baik maka hal tersebut menunjukkan tanggung jawab pemerintah yang lebih besar, sehingga kinerja pemerintah diharapkan meningkat.

Selain mempraktikkan prinsip good governance, pemerintah harus memiliki atau menerapkan sistem pengendalian intern pemerintah untuk meningkatkan transparansi dan akuntabilitas dalam melaksanakan tugas pemerintahan yang selanjutnya untuk peningkatan kualitas kinerja pemerintah. Sistem pengendalian intern adalah proses yang dirancang untuk menyediakan jaminan yang layak mengenai pencapaian dari sasaran menejemen yang dikategorikan sebagai efektivitas dan efisiensi oprasi, keandalan dari laporan keuangan, ketaatan pada hukum dan praturan yang berlaku (Arens, 2010:370). Sistem pengendalian intern pemerintah merupakan hal yang sangat penting dalam keberlangsungan suatu instansi pemerintahan. Sistem pengendalian intern pemerintah meliputi seluruh proses yang berkaita dengan pengawasan terhadap organisasi dalam rangka memberikan keyakinan yang memadai bahwa kegiatan telah dilaksanakan sesuai dengan tolok ukur yang telah ditetapkan.

Pengendalian intern yang baik akan menciptakan organisasi yang ekonomis, efektif, dan efisien untuk menciptakan good governance dalam organisasi yang akhirnya meningkatkan kinerja suatu organsisasi pemerintahan. Pengendalian intern merupakan hal yang mutlak harus diterapkan dalam suatu instansi pemerintah. 
Penelitian mengenai good governance dan sistem pengendalian intern sebelumnya sudah pernah dilakukan sebelumnya. Ulfa (2011) meneliti tentang pengaruh good governance, gaya kepemimpinan dan komitmen organisasi terhadap kinerja sektor publik pada Kabupaten Kampar, hasil penelitiannya menunjukkan hubungan yang signifikan antara good governance, gaya kepemimpinan dan komitmen organisasi terhadap kinerja sektor publik. Yusuf (2009) juga melakukan penelitian mengenai pengaruh good governance pada kinerja pemerintah Kota Bandung yang menunjukkan bahwa terdapat pengaruh yang signifikan antara penerapan good governance terhadap kinerja pemerintah Kota Bandung. Putri (2012) pada Satuan Kerja Perangkat Daerah (SKPD) Kota Padang, Tresnawati (2012) pada Dinas Pendapatan Kota Bandung dan Trihapsoro (2015) pada SKPD Kabupaten Boyolali melakukan penelitian tentang pengaruh sistem pengendalian intern pemerintah pada kinerja penelitian tersebut menemukan hasil yang sama, sistem pengendalian intern berpengaruh terhadap kinerja. Trisnaningsih (2007) menemukan hasil yang berbeda yaitu good governance tidak berpengaruh langsung terhadap kinerja auditor, melainkan berpengaruh tidak langsung melalui independensi auditor. Penelitian yang dilakukan oleh Boritz dan Jee (2007) dan Santoso (2016) juga menunjukkan hasil yang berbeda, penelitian ini menemukan bahwa sistem pengendalian intern tidak berpengaruh terhadap kinerja. Hasil penelitian yang tidak konsisten memotivasi untuk dilakukannya kembali penelitian serupa. Fakta kinerja pemerintah Kabupaten Karangasem menunjukkan masih banyak perlu pembenahan utamanya untuk membawa nama baik Kabupaten Karangasem. 
I Gede Agus Sudiarsana Putra dan I Made Pande Dwiana Putra. Pengaruh...

Tujuan penelitian adalah untuk untuk menganalisis pengaruh good governance pada Kinerja Pemerintah Daerah Kabupaten Karangasem serta menganalisis pengaruh sistem pengendalian intern pada Kinerja Pemerintah Daerah Kabupaten Karangasem. Harapannya penelitian ini mampu menambah bukti empiris dari penelitian-penelitian sebelumnya, bahwa teori keagenan mampu menjawab permasalahan yang ada dalam penelitian ini, serta mengenai bagaimana good governance dan sistem pengendalian intern pemerintah memengaruhi kinerja pemerintah daerah. Penelitian ini diharapkan dapat menjadi referensi dalam melakukan penelitian selanjutnya dengan menggunakan variabel yang lain dan sumbangan pemikiran yang diharapkan dapat meningkatkan kinerja Pemerintah Daerah Kabupaten Karangasem.

Berdasarkan landasan teori dan kajian empiris penelitian sebelumnya, maka peneliti merumuskan kerangka konsep penelitian seperti pada Gambar 1 sebagai berikut.

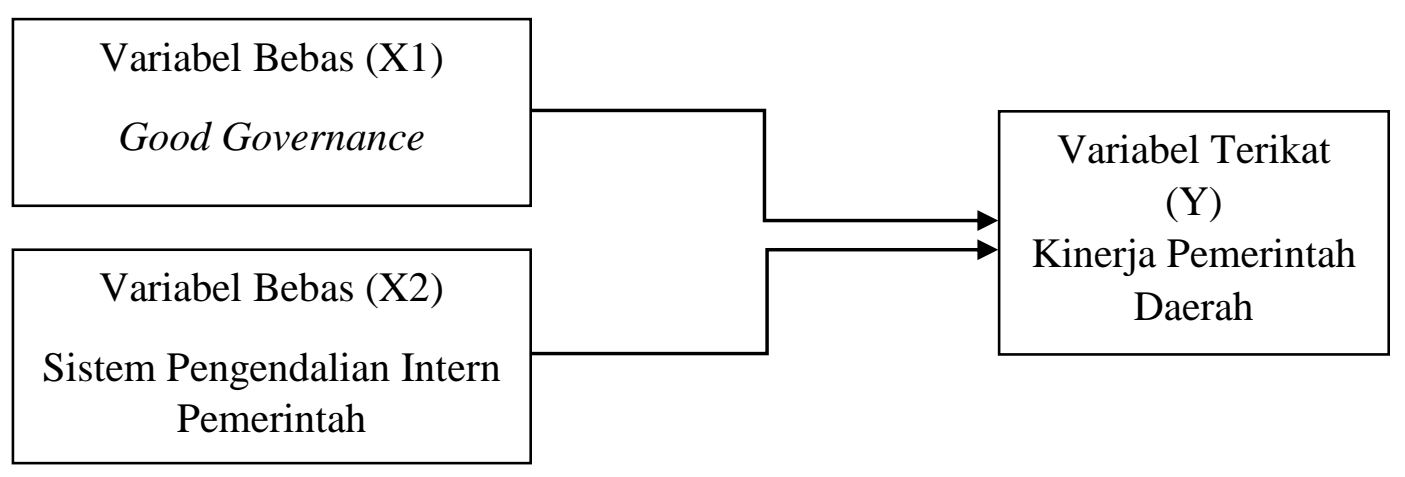

\section{Gambar 1. Kerangka Konseptual Penelitian}

Teori keagenan dapat dipandang sebagai model kotraktual antara dua pihak atau lebih, dimana salah satu pihak disebut agen dan pihak lain disebut prinsipal. Agen adalah orang yang diberi kuasa oleh prinsipal, sedangkan prinsipal adalah pemilik perusahaan (Eisenhardt, 1989). Jika kedua belah pihak memiliki 
tujuan yang sama, maka akan meningkatkan nilai dari organisasi. Pencapaian suatu tujuan dan kinerja organisasi tidak terlepas dari kinerja manajemen organisasi, sehubungan dengan itu hubungan antara manajemen dengan pemilik akan dituangkan dalam suatu kontrak. Hubungan keagenan pada instansi pemerintah yaitu agen diasumsikan sebagai pihak yang berwenang didalam pengambilan keputusan dan pengelolaan yang berkaitan dengan organisasi atas nama pemilik (Yessi, 2015). Anthony dan Govindarajan (2005:269) mengemukakan bahwa teori keagenan menjelaskan fenomena yang terjadi apabila atasan mendelegasikan wewenang kepada bawahan untuk melakukan suatu otoritas atau tugas dalam membuat keputusan. Lubis (2011:91) menyatakan pandangan terhadap teori keagenan yaitu kinerja dari organisasi ditentukan berdasarkan usaha dan pengaruh dari kondisi lingkungan. Konsep dari teori keagenan ini adalah adanya pemisahan fungsi antara pemilik (prinsipal) dan pengelola (agen). Berkaitan degan penelitian ini yang bertindak sebagai prinsipal yaitu masyarakat. Dari segi pengelolaannya masyarakat mendelegasikan tugas pengelolaan pemerintahan kepada agen. Adanya pelimpahan tugas dari prinsipal ke agen ini, dapat menimbulkan adanya hubungan keagenan. Adanya hubungan keagenan disini memungkinkan timbulnya permaslahan seperti asimetri informasi dan konflik kepentingan.

Teori keagenan menjelaskan bahwa good governance merupakan cara pengelolaan perusahaan secara efektif dan efisien untuk mencapai tujuan dari organisasi. Pemerintah yang mempraktikkan prinsip-prinsip good governance diharapkan mampu mendukung kelancaran dan keterpaduan pelaksanaan tugas 
I Gede Agus Sudiarsana Putra dan I Made Pande Dwiana Putra. Pengaruh...

dan fungsi penyelenggaraan pemerintah dan pembangunan secara efektif dan efisien. Dalam penelitian ini, prinsip good governance menjadi dimensi tolok ukur bagi pimpinan untuk mengambil keputusan. Keputusan yang tepat diambil oleh pimpinan akan mempengaruhi kinerja pemerintah.

Zeyn (2011) dalam penelitiannya mengenai pengaruh good governance terhadap akuntabilitas keuangan pemerintah Kota Bandung menunjukkan bahwa penerapan good governance memiliki pengaruh yang signifikan terhadap akuntabilitas keuangan pemerintah Kota Bandung, artinya good governance memiliki pengaruh terhadap kinerja pemerintahan. Yusuf (2009) juga melakukan penelitian mengenai pengaruh good governance pada kinerja pemerintah Kota Bandung bahwa terdapat pengaruh yang signifikan antara penerapan good governance terhadap kinerja pemerintah Kota Bandung dimana terdapat korelasi yang sangat kuat antara penerapan prinsip good governance pada kinerja pemerintah daerah yang dimana apabila terjadi penurunan atau peningkatan good governance akan berpengaruh pada kinerja pemerintah. Dari pernyataan di atas maka dapat diungkapkan bahwa apabila semakin baik penerapan good governance semakin baik pula kinerja pemerintah di daerah tersebut.

$\mathrm{H}_{1}$ : Good Governace berpengaruh positif pada Kinerja Pemerintah Daerah Kabupaten Karangasem.

Peraturan Pemerintah Nomor 60 Tahun 2008 menyebutkan bahwa SPIP adalah proses integral pada tindakan dan kegiatan yang dilakukan secara terusmenerus oleh pimpinan dan seluruh pegawai untuk memberikan keyakinan memadai atas terciptanya tujuan organisasi melalui kegiatan yang efektif dan efisien, keandalan pelaporan keuangan, pengamanan aset negara, dan ketaatan 
pada peraturan perundang-undangan. Teori keagenan menjelaskan kegiatan pengendalian dapat memberikan arah bagi pimpinan organisasi pemerintah agar dapat mencapai tujuan organisasi dengan efektif dan efisien serta sesuai dengan ukuran, kompleksitas dan sifat dari tugas dan fungsi suatu instansi pemerintah yang bersangkutan. Kegiatan pengendalian terdiri atas pengawasan dan revew atas kinerja instansi pemerintah yang bersangkutan. Sistem pengendalian yang baik akan menciptakan keseluruhan proses kegiatan yang baik pula, sehingga nantinya dapat memberikan keyakinan kepada stakeholders bahwa aktivitas yang dilaksanakan telah berjalan sesuai dengan peraturan perundang-undangan yang berlaku.

Sistem pengendalian intern pemerintah merupakan dimensi tolok ukur dari suatu kinerja, dimana jika semakin baik sistem pengendalin intern pemerintah disuatu pemerintahan maka fungsi dan tugas penyelenggara pemerintah akan berjalan dengan efektif dan efisien, kemudian kinerja yang dihasilkan suatu pemerintahan tersebut akan meningkat. Penelitin yang dilakukan oleh Trihapsoro (2005) yang berjudul pengaruh kualitas sumberdaya manusia, pemanfaatan teknologi informasi dan sistem pengendalian intern pemerintah terhadap kinerja yang dilakukan pada Satuan Kerja Perangkat Daerah (SKPD) Kabupaten Boyolali, menemukan bahwa sistem pengendalian intern berpengaruh positif dan signifikan terhadap kinerja. Penelitian oleh Yolanda (2012) menunjukkan sistem pengendalian intern pemerintah berpengaruh positif dan signifikan terhadap kinerja manajerial SKPD, dan Almanda (2013) menunjukkan bahwa pengawasan intern berpengaruh positif dan signifikan terhadap Kinerja Pemerintah Daerah. 
I Gede Agus Sudiarsana Putra dan I Made Pande Dwiana Putra. Pengaruh...

Ketiga penelitian tersebut menujukkan hasil yang sama. Berdasarkan uraian di atas dapat disimpulkan bahwa semakin baik penerapan sistem pengendalian intern pemerintah maka semakin baik juga kinerja yang akan dihasikan.

$\mathrm{H}_{2}$ : Sistem Pengendalian Intern Pemerintah (SPIP) berpengaruh positif pada Kinerja Pemerintah Daerah Kabupaten Karangasem

\section{METODE PENELITIAN}

Lokasi penelitian merupakan tempat penelitian akan dilakukan. Penelitian ini dilakukan di Organisasi Perangkat Daerah (OPD) Kabupaten Karangasem yang terdiri dari 40 OPD. Lokasi ini dipilih karena sepengetahuan peneliti belum ada penelitin serupa yang meneliti di OPD Kabupaten Karangasem terkait penelitian setahun terakhir, sehingga peneliti tertarik dan memutuskan untuk meneliti diwilayah tersebut. Objek pada penelitian ini adalah Kinerja Pemerintah Daerah Kabupaten Karangasem.

Kinerja pemerintah daerah adalah prestasi kerja yang diperoleh atau dicapai pemerintah daerah dalam merealisasikan target dan tujuan awal yang telah ditetapkan secara efektifdan efisien. Indikatornya adalah pencapaian target kinerja dari suatu program, ketepatan dan kesesuaian hasil, dampak hasil kegiatan terhadap kehidupan masyarakat, dan moral pegawai (Hermaningsih, 2009). Instrumen yang dipakai dalam mengukur variabel ini adalah pernyataan dalam kuesioner yang diadopsi dari Hermaningsih (2009) dengan 7 daftar pernyataan.

Good governance adalah tata pemerintahan yang baik yang solid dan bertanggungjawab, serta efektif dan efisien dengan menjaga interaksi yang konstruktif diantara domain-domain negara, sektor swasta dan masyarakat (Halim dan Damayanti, 2007:83). Indikator untuk variabel good governance adalah 
sebagai berikut: Partisipasi, Aturan Hukum, Transparansi, Daya Tanggap, Kesetaraan, Efektifitas dan Efisiensi, Akuntabilitas, dan Visi Strategik. Instrumen yang digunakan dalam penelitian ini adalah pernyataan dalam kuesioner yang diadopsi dari Badruzaman dan Chairunnisa (2011) dengan 15 daftar pernyataan.

Peraturan Pemerintah Nomor 60 Tahun 2008 menyebutkan bahwa SPIP adalah proses integral pada tindakan dan kegiatan yang dilakukan secara terus menerus oleh pimpinan dan seluruh pegawai untuk memberikan keyakinan memadai atas terciptanya tujuan organisasi melalui kegiatan yang efektif dan efisien, keandalan pelaporan keuangan, pengamanan asset negara, dan ketaatan pada peraturan perundang-undangan. Indikator yang digunakan dalam variabel SPIP adalah sebagai berikut: lingkungan pengendalian, penilaian risiko, kegiatan penilaian, informasi dan komunikasi, dan pemantauan pengendalian intern. Instrumen dalam penelitian ini adalah pernyataan dalam kuesioner yang diadopsi dari Ruspina (2013) dengan 15 daftar pernyataan.

Populasi dalam penelitian ini adalah pejabat OPD yang berjumlah 200 orang yang tersebar dalam 40 OPD. Sampel yang digunakan dalam penelitian ini ditentukan dengan menggunakan metode purposive sampling. Kriteria yang ditetapkan dalam penelitian ini antara lain: 1). Aparatur Sipil Negara (ASN) yang menjabat sebagai kepala di dalam OPD, kriteria ini dipilih karena kepala memiliki peran atau tugas memimpin, merencanakan, mengawasi, mengendalikan dan mengkoordinasikan kegiatan dalam menyelenggarakan urusan pemerintahan, sehingga kepala OPD dianggap berhubungan langsung dengan kegiatan di suatu Pemerintahan; 2). ASN yang menjabat sebagai sub bagian perencanaan, sub 
I Gede Agus Sudiarsana Putra dan I Made Pande Dwiana Putra. Pengaruh...

bagian keuangan, dan sub bagian umum dan kepegawaian di dalam OPD, kriteria ini digunakan karena memiliki tugas menyusun rencana pelaksanaan program kegiatan, pengelolaan keuangan, dan pertanggungjawaban administrasi keuangan secara langsung, sehingga bisa memberikan respon yang sebagaimana kenyataannya; 3). Minimal telah menduduki jabatan satu tahun, dikarenakan pemilihan jabatan satu tahun merupakan hal yang relatif dalam suatu organisasi. Total sampel yang digunakan dalam penelitian ini berdasarkan kriteria responden OPD Kabupaten Karangasem adalah 160 orang dari 40 OPD Kabupaten Karangasem.

Penelitian ini dilakukan uji asumsi klasik terlebih dahulu kemudian dilakukan teknik analisis data. Teknik analisis data dalam penelitian ini menggunakan uji Analisis Regresi Linear Berganda. Penelitian ini menggunakan analisis regresi linear berganda, karena terdiri dari satu variabel dependen dan beberapa variabel independen. Model regresi linear berganda ditunjukkan oleh persamaan regresi berikut.

$$
\mathrm{Y}=\alpha+\beta_{1} \mathrm{X}_{1}+\beta_{2} \mathrm{X}_{2}+\varepsilon
$$

Keterangan:

$$
\begin{array}{lll}
\mathrm{Y} & = & \text { Kinerja Pemerintah Daerah } \\
\mathrm{X}_{1}= & \text { Good Governance } \\
\mathrm{X}_{2}= & \text { Sistem Pengendalian Intern Pemerintah } \\
\alpha= & \text { Konstanta } \\
\beta_{1}, \beta_{2}= & \text { Koofisien regresi dari masing-masing variabel } \\
\varepsilon= & \text { Variabel pengganggu }
\end{array}
$$

\section{HASIL DAN PEMBAHASAN}

Kabupaten Karangasem terletak terletak di ujung timur Pulau Bali dan merupakan salah satu dari 9 Kabupaten/Kota yang ada di Provinsi Bali. Secara geografis 
Kabupaten Karangasem berada di antara 8000'00" - 8047'37,8” lintang selatan dan 115035 '9,8'- 115054'8,9' bujur timur. Luas Kabupaten Karangasem adalah $839,54 \mathrm{~km}^{2}$ atau 14,90 persen dari luas wilayah Provinsi Bali. Secara administratif Kabupaten Karangasem dibagi menjadi 8 kecamatan (www.karangasemkab.go.id)

Sebelum dilakukan uji regresi linear berganda, dilakukan uji instrumen terlebih dahulu. Instrumen yang valid berarti instrumen yang dapat digunakan untuk mengukur apa yang seharusnya diukur. Tinggi rendahnya validitas menunjukan sejauh mana data yang terkumpul tidak menyimpang dari gambarangambaran tentang variabel yang dimaksud. Variabel good governance, sistem pengendalian intern pemerintah dan kinerja pemerintah daerah memiliki Pearson's Correlation secara berturut-turut dari 0,381 - 0,603 (>0,30), dari 0,359 - 0,623 (>0,30), dan dari 0,495 - 0,615 (>0,30) dengan tingkat signifikansi ketiga variabel diatas memiliki nilai yang sama yaitu $0,000<0,05$. Ketiga variabel tersebut memiliki nilai di atas 0,30 dan tingat signifikasi dibawah 0,05 yang artinya pernyataan kuesioner dari ketiga variabel tersebut adalah valid.

Instrumen yang reliable adalah suatu instrument yang bila digunakan beberapa kali untuk mengukur objek yang sama, maka akan menghasilkan data yang sama. Instrument dikatakan reliable untuk mengukur variabel bila memiliki nilai Cronbach Alpha $>0,60$. Hasil uji reliabilitas instrumen pada penelitian ini yang menunjukkan bahwa kelima instrumen penelitian memiliki koefisien cronbach's alpha yang lebih besar dari angka 0,60 sehingga pernyataan pada kuesioner dapat dikatakan reliabel. 
I Gede Agus Sudiarsana Putra dan I Made Pande Dwiana Putra. Pengaruh...

Statistik deskriptif digunakan untuk memberikan informasi mengenai karakteristik variabel-variabel penelitian, yaitu jumlah sampel, nilai rata-rata (Mean), nilai minimum dan maksimum, serta standar deviasi pada variabelvariabel yang diteliti. Hasil Statistik deskriptif dapat dilihat pada Tabel 2.

Tabel 2.

Hasil Statistik Deskriptif

\begin{tabular}{cccccc}
\hline Variabel & N & Min. & Max. & Mean & $\begin{array}{c}\text { Std. } \\
\text { Deviasi }\end{array}$ \\
\hline Good Governance & 152 & 52 & 75 & 64,03 & 4,611 \\
Sistem Pegendalian Intern & 152 & 51 & 75 & 62,40 & 5,206 \\
$\begin{array}{c}\text { Pemerintah } \\
\text { Kinerja Pemerintah }\end{array}$ & 152 & 23 & 35 & 29,71 & 2,394 \\
\hline Sumber: Data diolah, 2018 & & & & &
\end{tabular}

Sumber: Data diolah, 2018

Variabel good governance memiliki nilai minimum sebesar 52, sedangkan nilai maximum sebesar 75. Mean dari good governance sebesar 64,03 artinya bahwa nilai rata-rata good governance pada 38 OPD adalah 64,03 . Nilai rata-rata good governance lebih mendekati nilai maximum, hal ini berarti penerapan good governance pada OPD cenderung tinggi. Standar deviasi sebesar 4,611 artinya terdapat perbedaan good governance terhadap nilai rata-ratanya sebesar 4,611.

Variabel sistem pengendalian intern pemerintahmemiliki nilai minimum sebesar 51, sedangkan nilai maximum sebesar 75. Mean dari sistem pengendalian intern pemerintan sebesar 62,40 artinya bahwa nilai rata-rata sistem pengendalian intern pemerintah pada 38 OPD adalah 62,40 . Nilai rata-rata sistem pengendalian intern pemerintah lebih mendekati nilai minimum, hal ini berarti penerapan sistem pengndalian intern pemerintah pada OPD cenderung rendah. Standar deviasi sebesar 5,206 artinya terdapat perbedaan sistem pengendalian intern terhadap nilai rata-ratanya sebesar 5,206. 
Variabel kinerja pemerintah memiliki nilai minimum sebesar 23, sedangkan nilai maximum sebesar 35. Mean dari kinerja pemerintah sebesar 29,71 artinya bahwa nilai rata-rata good governance pada 38 OPD adalah 29,71. Nilai rata-rata kinerja pemerintah lebih mendekati nilai maximum, hal ini berarti kinerja pemerintah pada OPD cenderung tinggi. Standar deviasi sebesar 2,394 artinya terdapat perbedaan good governance terhadap nilai rata-ratanya sebesar 2,394.

Selanjutnya dilakukan uji asumsi klasik, model persamaan regresi berdistribusi normal karena memiliki nilai Kolmogorov Smirnov sebesar 0,0904lebih besar dari 0,05. Nilai signifikansi masing-masing variabel lebih besar dari 0,05 sehingga dapat disimpulkan bahwa model regresi bebas dari gejala heteroskedastisitas. Nilai tolerance dan VIF dari seluruh variabel tersebut menunjukkan bahwa nilai tolerance untuk setiap variabel lebih besar dari $10 \%$ dan nilai VIF lebih kecil dari 10 yang berarti model persamaan regresi bebas dari multikolinearitas.

Setelah semua asumsi klasik terpenuhi, maka selanjutnya memaparkan hasil analisis regresi linier berganda. Hasil pengujian disajikan pada Tabel 3 berikut ini.

Tabel 3.

Hasil Analisis Regresi Linier Berganda

\begin{tabular}{crrrr}
\hline Variabel & Unstandardized Beta & Std. Error & T hitung & Sig. uji t \\
\hline (Constant) & 15,138 & 3,060 & 4,947 & 0,000 \\
Good Governace & 0,134 & 0,040 & 3,321 & 0,001 \\
Sistem Pengendalian Intern & 0,096 & 0,036 & 2,665 & 0,009 \\
Pemerintah & & & & 0,121 \\
Adjust R Square & & & 11,378 \\
F Statistik & & & 0,000 \\
Signifikansi Uji F & & &
\end{tabular}


I Gede Agus Sudiarsana Putra dan I Made Pande Dwiana Putra. Pengaruh...

Berdasarkan hasil analisis regresi linier berganda seperti yang disajikan pada Tabel 3, maka dapat dibuat persamaan regresi sebagai berikut:

$$
Y=15,138+0,134 X_{1}+0,096 X_{2}+\varepsilon
$$

Nilai signifikansi F pada Tabel $3=0,000$ menunjukkan bahwa signifikansi F lebih kecil dari $\alpha(0,05)$, ini berarti model yang digunakan penelitian adalah layak.Hasil ini mempunyai arti bahwa ada pengaruh faktor Good Governance dan Sistem Pengendalian Intern Pemerintah pada Kinerja Pemerintahan Daerah Kabupaten Karangasem. Uji koefisien determinasi digunakan untuk mengetahui kemampuan model dalam menerangkan variansi variabel dependen menggunakan koefisien determinasi $\left(\mathrm{R}^{2}\right)$. Nilai adjusted $\mathrm{R}$ Square sebesar 0,121 mempunyai arti bahwa sebesar 12,1 persen variansi Kinerja Pemerintah di Kabupaten Karangasem dipengaruhi oleh Good Governance dan Sistem Pengendalian Intern Pemerintah, sedangkan sisanya sebesar 87,9 persen dijelaskan oleh faktor lain yang tidak dimasukkan ke dalam model.

Hasil perhitungan yang ditunjukkan pada Tabel 3 diketahui bahwa variabel good governance berpengaruh positif pada kinerja. Hipotesis pertama $\left(\mathrm{H}_{1}\right)$ yang menyatakan good governance berpengaruh pada kinerja pemerintah daerah diterima. Tujuan penelitian ini adalah untuk mengetahui pengaruh Good Governance pada Kinerja Pemerintah Daerah Kabupaten Karangasem. Hasil penelitian ini menunjukkan bahwa good governance berpengaruh positif pada kinerja pemerintah. Hal ini sejalan dengan teori agensi yang digunakan, bahwa pemerintah sebagai agen wajib melaksanakan tuga-tugas dari masyarakat dengan memastikan pengendalian dan pengelolaan yang sesuai, sehingga sasaran dari 
organisasi bisa tercapai dengan cara yang efektif dan efisien. Hasil penelitian ini mendukung penelitian Zeyn (2011), Ulfa (2011), yang menunjukkan penerapan good governance bertujuan untuk pengelolaan organisasi yang lebih baik, sehingga sumber daya yang ada di daerah dapat dipergunakan dengan baik untuk mencapai tujuan dari organisasi pemerintah yaitu kesejahtraan serta peningkatan kualitas masyarakat. Hal tersebut mencerminkan tercapainya kinerja pemerintah seperti yang diharapkan. Lebih lanjut Umar (2011), Nathmy et al. (2015), dan Alaarj dan Hassan (2016) menyatakan bahwa para pembuat kebijakan di pemerintahan memiliki wewenang prioritas dalam membuat keputusan-keputusan untuk pengelolaan negara yang lebih beretika dan terutama untuk mengurangi korupsi dan membuat kebijakan yang lebih mengutamakan kepentingan masyarakat untuk meningkatkan kepercayaan masyarakat.

Hasil ini memiliki arti bahwa semakin baik penerapan Good Governance maka semakin baik pula Kinerja Pemerintah Kabupaten Karangasem, sebaliknya apabila semakin rendah penerapan Good Governance semakin rendah pula tingkat Kinerja Pemerintah Kabupaten Karangasem. Penerapan good governance yang baik dan konsisten dilakukan pemerintah Kabupaten Karangasem, maka pengelolaan sumber daya yang ekonomis, efektif dan efisien akan tepat pada sasaran, sehingga pengelolaan yang efektif dan efisien serta tepat sasaran merupakan cerminan dari kinerja yang membaik.

Hasil perhitungan yang ditunjukkan pada Tabel 3. diketahui bahwa variabel sistem pengendalian intern pemerintah berpengaruh positif pada kinerja pemerintah. Hipotesis kedua $\left(\mathrm{H}_{2}\right)$ yang menyatakan sistem pengendalian intern 
I Gede Agus Sudiarsana Putra dan I Made Pande Dwiana Putra. Pengaruh...

pemerintah berpengaruh pada kinerja pemerintah daerah diterima. Hasil penelitian ini mendukung teori agensi yang menyatakan pengendalian memberikan arahan bagi pimpinan unrtuk pengambilan keputusan guna mengelola organisasi secara efektif dan efisien. Hasil ini juga mendukung penelitian yang dilakukan Trihapsoro (2015) dan Zakaria et al. (2006) yang menyatakan bahwa semakin baik sistem pengendalian intern di suatu organisasi pemerintahan akan menciptakan kinerja pemerintah yang baik pula.

Putri (2013) menyatakan bahwa sistem pengendalian intern yang baik dalam suatu organisasi mampu menciptakan keseluruhan proses yang baik, sehingga akan memberikan suatu keyakinan terhadap stakeholders bahwa aktivitas yang dilakukan sudah sesuai dengan tolok ukur yang telah ditetapkan. Pemerintah yang memiliki komitmen dalam mencapai tujuan akan memengaruhi tindakannya untuk mematuhi sistem pengendalian intern yang ada. Semakin tinggi tingkat kepatuhan pemerintah pada sistem pengendalian yang ada, maka semakin tinggi kinerja pemerintah di daerah. Hasil ini menunjukkan semakin baik sistem pengendalian intern pemerintah, semakin baik pula kinerja Pemerintah Kabupaten Karangasem.

Penelitian ini memberikan tambahan informasi mengenai good governance dan sistem pengendalian intern pemerintah serta memperoleh pemahaman yang lebih baik tentang teori keagenan serta dampaknya pada kinerja pemerintah daerah.Penelitian ini memberikan sumbangan untuk pemerintah daerah yaitu agar pemerintah daerah benar-benar mempertimbangkan good governance sebagai alat yang mutlak diterapkan disuatu pemerintah, sehingga nantinya akan berdampak pada kinerja. Penerapan good governance pada instansi pemerintah dilakukan itu 
karena prinsip dasar dari good governance itu dapat meningkatkan kepercayaan masyarakat pada pemerintah.

\section{SIMPULAN}

Berdasarkan hasil analisis data dan pembahasan yang telah dipaparkan pada bab sebelumnya, dapat dijelaskan bahwa dari dua hipotesis yang diajukan, seluruh hipotesis dapat diterima. Adapun kesimpulan dari hasil penelitian yang dilakukan adalah sebagai berikut: 1). Good Governance berpengaruh positif pada Kinerja Pemerintah Daerah Kabupaten Karangasem. Hal ini menunjukkan bahwa semakin baik penerapan good governance maka semakin baik pula Kinerja Pemerintah Daerah Kabupaten Karangasem; 2). Sistem Pengendalian Intern Pemerintah berpengaruh positif pada kinerja pemerintah daerah Kabupaten Karangasem. Hal ini mengindikasikan semakin baik sistem pengendalian intern pemerintah di Kabupaten Karangasem maka semakin meningkat Kinerja Pemerintah Daerah Kabupaten Karangasem.

Saran yang dapat diberikan adalahgood governance dan sistem pengendalian intern merupakan faktor pendorong peningkatan kinerja. Hal ini mengungkapkan bahwa sebaiknya instansi pemerintah daerah khususnya OPD Kabupaten Karangasem lebih memperhatikan faktor tersebut, sehingga kinerja suatu organisasi pemerintah bisa dikatakan baik.Pemerintah Kabupaten Karangasem harus lebih memperhatikan indikator transparansi, dimana masyarakat dapat mengakses informasi dari instansi pemerintah terkait kinerja dari pemerintah. Jika informasi sudah bisa diakses oleh masyarakat, maka akan 
I Gede Agus Sudiarsana Putra dan I Made Pande Dwiana Putra. Pengaruh...

meningkatkan kepercayaan masyarakat pada pemerintah bahwa semua kegiatan dipemerintahan sudah berjalan dengan baik.

Pemerintah Kabupaten Karangasem harus lebih memperhatikan penilaian risiko sebelum mengambil keputusan, karena hasil survey menemukan bahwa nilai penilaian risiko memperoleh nilai paling rendah. Pengambilan keputusan yang berdasarkan resiko akan membuat pimpinan mengambil keputusan yang tepat. Bagi peneliti selanjutnya diharapkan dapat melakukan penelitian pada instansi daerah lainnya di Bali maupun diluar Daerah Bali sehingga menjadi tergeneralisasi.

\section{REFERENSI}

Alaaraj, Hassan dan Sallahudin Hassan. 2016. Does Good Governance Mediate Relationship between E-Government and Public Trust In Lebanon? International Revew of Management and Marketing, 6 (3): 500-509.

Arens, Alvin A., Randal J. Elder, dan Mark S. Beasley. 2010. Auditing and Assurance Service: An Intergreted Approach, $13^{\text {th }}$ Edition, New Jersey: Pearson, Prentice Hall Inc.

Badan Pemeriksa Keuangan. Ikhtisar Hasil Pemeriksaan Semester. http://www.bpk.go.id/ihps. Diunduh 19 Januari 2018.

Badruzaman, Jajang dan Chairunnisa, Irna 2011. Pengaruh Instansi Implementasi Sistem Akuntabilitas Kinerja Instansi Pemerintah (SAKIP) Terhadap Penerapan Good Governance. Jurnal Akuntansi Dan Bisnis AUDI, 7(1): 57-70.

Boynton, W. C., dan Jonson, R. N. 2006. Modern Auditing: Assurance Services and the Integrity of Financial Reporting. $8^{\text {th }}$ Edition, New Jersey: John Wiley and Sons.

Eisenhardt, K.M. 1989. Agency theory: An Assessment and Review. Academy Of Management Review, 14 (14):57-54.

FCGI (Forum for Corporate Governance in Indonesia).2002. Tata Kelola Perusahaan (Corporate Governance) the Essence of Good Corporate Governance. Konsep dan Implementasi Perusahaan Publik dan Korporasi 
Indonesia.Yayasan Pendidikan Pasar Modal Indonesia \& Synergy Communication. Jakarta

Hasanah, Cucu Ulvani., dan Suartana, I Wayan. 2014. Pengaruh Interaksi Motivasi dan Budaya Organisasi Pada Hubungan Antara Partisipasi Penyusunan Anggaran Dengan Senjangan Anggaran. E-Jurnal Akuntansi Universitas Udayana, 6(1): 46-62

Hermaningsih, 2009. Pengaruh Partisipasi Dalam Penganggaran dan Peran Manajerial Pengelola Keuangan Daerah Pada Kinerja Pemerintah Daerah (Studi Empiris Pada Pemerintah Kabupaten Demak). Tesis. Universitas Diponegoro. Semarang.

Jensen, M, C., dan Meckling, William H. 1976. Theory of the Firm Managerial Behavior Agency Casts And Ownership Structure. Journal of Financial Economics, 3(4): 305-360.

Mahoney, T. A., T. H. Jardee, dan S. J. Carrol. 1963. Development of Managerial Ferformance: A. Research Appoarch. Cincinnati, OH: South Western Publishing Company.

Nathmy, E. I., S. F. Al-Around, dan T. H. Almbaidin. 2015. The Effect of the Absence Of The Aplication Of The Mechanisms Of Corporate Governance Jordanian Ministries. Advances in management \& applied economics. 5(4): 66-77.

Putri, Gustika Yolanda. 2013. Pengaruh Komitmen Organisasi dan Sistem Pengendalian Intern (SPIP) Pada Kinerja Manajerial SKPD (Studi Empiris Pada Satuan Kerja Perangkat Daerah Kota Padang). Tesis. Universitas Negeri Padang.

Retno, Reny Dyah dan Priantinah, Denies. 2012. Pengaruh Good Corporate Governance dan Pengungkapan Corporate Sosial Responsibility terhadap Nilai Perusahaan. Jurnal Nominal. 1(1): 84-103.

Ruspina, Depi Oktia 2013. Pengaruh Kinerja Aparatur Pemerintah Daerah, Pengelolaan Keuangan Daerah, dan Sistem Pengendalian Intern Pemerintah (SPIP) Pada Penerapan GoodGovernance (Studi Empiris Pada Pemerintahan Kota Padang). Jurnal Universitas Negeri Padang. 1(3): 2024

Santoso, Eli Budi. 2016. Pengaruh Sistem Pengendalian Intern Pemerintah, Pemanfaatan Teknologi Informasi dan Kompentensi Sumber Daya Manusia terhadap Akuntabilitas Keuangan Daerah. Tesis. Universitas Lampung. 
Todorovic, Igor dan Zdravko Toodorovic. 2012. Compliance with Modern Legislation Of Corporate Governance And Its Implemention In Companies. Montenegrin Journal of Economics, 8 (2): 230-240

Trihapsoro, Argo. 2015. Pengaruh Kualitas Sumberdaya Manusia, Pemanfaatan Teknologi Informasi dan Sistem Pengendalian Intrn Pemerintah Terhadap Kinerja Pemerintah Daerah. Jurnal Universitas Muhamadyah Surakarta, 1 (3): 19-27

Trinsnaningsih, Sri. 2017. Independensi Auditor dan Komitmen Organisasi Sebagai Mediasi Pengaruh pemahaman Good Governance, Gaya Kepemimpinan dan Budaya Organisasi Pada Kinerja Auditor. Simposium Nasional Akuntansi X Universitas Hasanudin. Makasar.

Ulfa, Fimela. 2011. Pengaruh Good Governance, Gaya Kepemimpinan, danKomitmen Organisasi Terhadap Kinerja Sektor Publik. Jurnal Akuntansi Universitas Riau, 10 (3): 20-31

Umar, Haryono. 2011. Government Financial Management, Strategy for Preventing Corruption in Indonesia. The South East Asian Journal of Management, 5 (1): 19-35.

Widiari, Putu Ayu. 2015. Peran Good Goverment Governance Dalam Memoderasi Pengaruh Partisipasi Penyusunan Anggaran Pada Kinerja Pemerintah Daerah Kota Denpasar. Tesis. Universitas Udayana: Bali.

Wulandari, Nur Endah. 2011. Pengaruh Partisipasi Penyusunan Anggaran Pada Kinerja Aparat Pemerintah Daerah: Kepuasan Kerja dan Komitmen Organisasi Sebagai Variabel Pemoderasi. Thesis Undergraduate. Universitas Diponegoro.

Zakaria, Zamzulaila, Susela Devi Selvaraj, dan Zarrina Zakaria. 2006. Internal Auditors: Their Role in the Institutions of Higers Education in Malaysia. Managerial Auditing Journal. 21: 892-904.

Zeyn, Elvira. 2011. Pengaruh Good Governance dan Standar Akuntansi Pemerintahan terhadap Akuntabilitas Keuangan dengan komitmen organisasi sebagai pemoderasi. Jurnal Review Akuntansi dan Keuangan, 1(1): 21-37. 